\title{
The Mostafa Maged four-stitch technique to avoid leaving dead space during repairing the episiotomy
}

\author{
Mostafa Maged Ali ${ }^{1 *}$, Laila Ezzat Abd-Elfattah ${ }^{2}$
}

\author{
${ }^{1}$ Department of Obstetrics and Gynecology, Ministry of Health, Fayoum, Egypt \\ ${ }^{2}$ Department of Obstetrics and Gynecology, Fayoum University, Fayoum, Egypt
}

Received: 27 October 2021

Accepted: 13 December 2021

\section{*Correspondence:}

Dr. Mostafa Maged Ali,

E-mail: Supermostafa200@yahoo.com

Copyright: (C) the author(s), publisher and licensee Medip Academy. This is an open-access article distributed under the terms of the Creative Commons Attribution Non-Commercial License, which permits unrestricted non-commercial use, distribution, and reproduction in any medium, provided the original work is properly cited.

\begin{abstract}
Most women who are primigravida are mostly confronted with episiotomy during child-birth to prevent the perineal and vaginal lacerations which could be performed at birth. There are many types of episiotomies which are median, mediolateral and J-shaped episiotomy. In here, we performed the mediolateral suture due to its safety. All episiotomy were taken by the Mostafa Maged four-stitch technique. Prevention of the formation of the dead space during the repair of episiotomy so avoiding hematoma formation in the episiotomy area after child-birth. It is an Interventional study. The Mostafa Maged four-stitch technique uses the absorbable vicryls treads with round needles $75 \mathrm{~mm}$. the results of this new technique are Prevention of the dead space formation, Good and tight hemostasis of the episiotomy is achieved, strong approximation of the two edges of the episiotomy, cosmetically, it is so good. The invention of this new technique (Mostafa Maged technique) has shown its effectiveness in those fifteen patients in preventing the dead space during suturing the episiotomy in primigravida cases.
\end{abstract}

Keywords: Primigravida, Episiotomy, Childbirth, Mostafa Maged

\section{INTRODUCTION}

First described by a Scottish midwife in the 1740s, episiotomy was not used widely until the middle of the 20th century. ${ }^{1}$ Prominent obstetricians in the United States argued that childbirth was a "decidedly pathological process" and that a small incision would speed labour, decrease trauma, and allow the perineum to be restored to nearly virginal condition after proper suturing. ${ }^{1}$

The episiotomy is a technique originally designed to reduce the incidence of severe perineal tears (third and fourth-degree) during labor. The two most common techniques are midline (the US and Canada) and mediolateral (Europe). ${ }^{2}$

A retrospective cohort study suggested that episiotomy use may put multiparous women at increased risk for third and fourth-degree tears. ${ }^{3}$
Mediolateral episiotomy is a safe obstetrical surgical procedure in order to prevent third- and fourth-degree perineal tears and is not associated with increased incidence of complications. ${ }^{4}$

After delivery, a rectal exam is warranted to assess the extent of the incision. A continuous running stitch with absorbable sutures during the repair is the recommended approach, as it reduces the need for further removal at a later date. ${ }^{5}$

The adverse effects of episiotomy include bleeding, prolonged wound healing, complications in subsequent vaginal deliveries, dyspareunia, pelvic floor dysfunction, urinary fistulas, and inappropriate wound scarring. ${ }^{6,7}$

The most important complication of an episiotomy is an injury to the external anal sphincter muscle, which can lead to incontinence and fistula formation. ${ }^{7}$ 
Although perineal pain and dyspareunia that occur in the postpartum period are considered the main issues that prevent normal sexual activity, knowledge on this issue is lacking because there are insufficient studies comparing ante- and postpartum sexual activity. perineal pain and dyspareunia results from perineal trauma, lacerations, episiotomy and forceps/vacuum use at delivery. ${ }^{8}$

\section{CASE SERIES}

The research protocol was approved by the university and ethics committee before the study began. All human participants gave written informed consent before the study began.

They are thirteen young patients. They are all primigravida. Their mean age is 26.5 years old; their mean gestational age is 37 weeks. The episiotomy is taken to all patients due to the narrow vaginal canal at childbirth time. Then, the episiotomy is repaired by (The Mostafa Maged four-stitch technique) to prevent the formation of the dead space._Patients with Primigravida pregnant females have episiotomy during labour. Age is between 20 and 35 years old included.

Also, the medical history of blood diseases as thalassemia or hemophilia, Age is more than 35 years old, Morbid obese patients whose BMI is more than $35 \mathrm{~kg} / \mathrm{m}^{2}$, and Smokers excluded from the study.

\section{Description of the new Mostafa Maged surgical technique}

In here we describe the technique, in here, we use the absorbable vicryls treads with round needles $75 \mathrm{~mm}$ long, providing the images below (Figures of the technique applied on a sponge model) to facilitate to understand the technique:

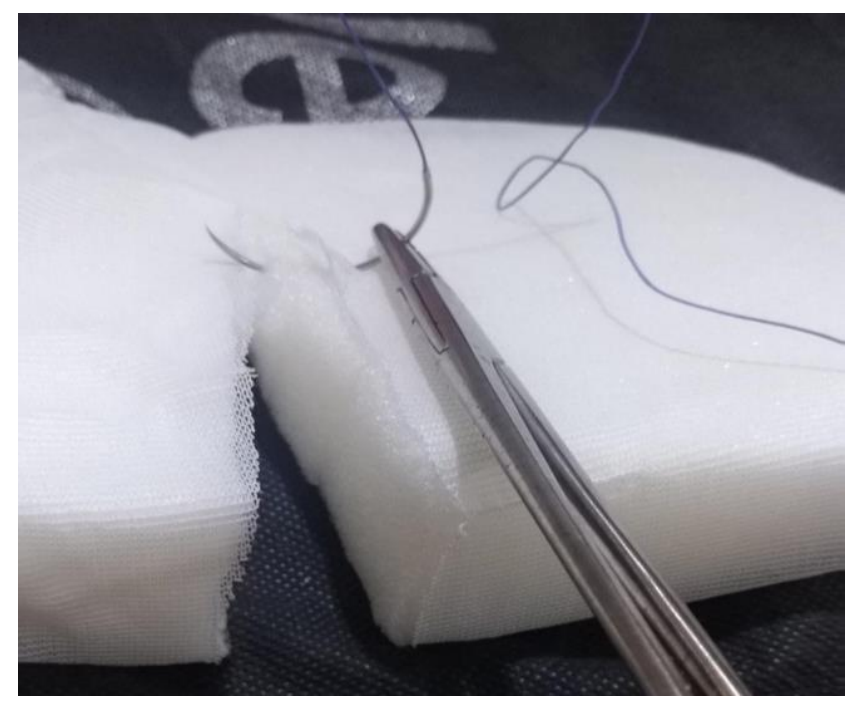

Figure 1: First, the needle is inserted at the vaginal epithelium of the right edge of the episiotomy incision then we extract the needle.

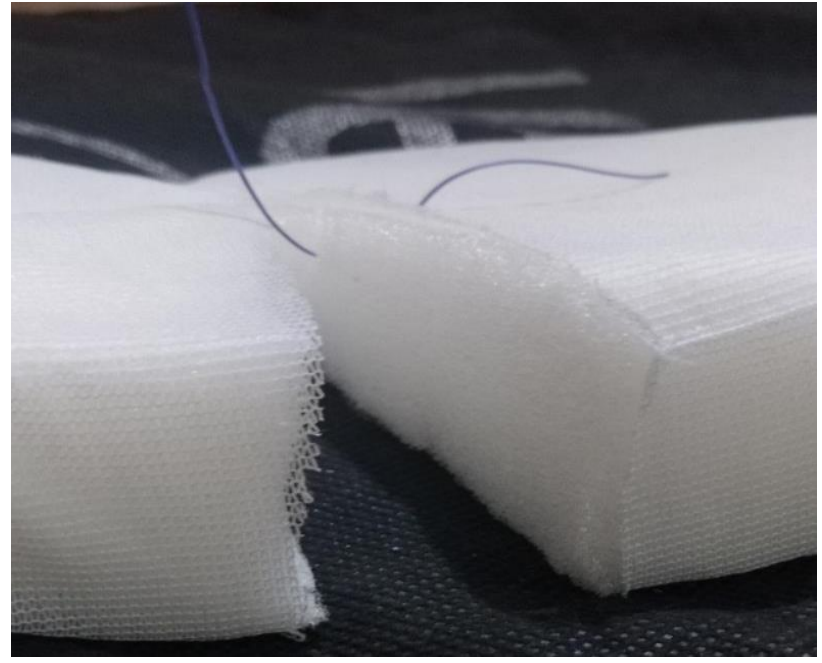

Figure 2: First, the needle is inserted at the vaginal epithelium of the right edge of the episiotomy incision then we extract the needle.

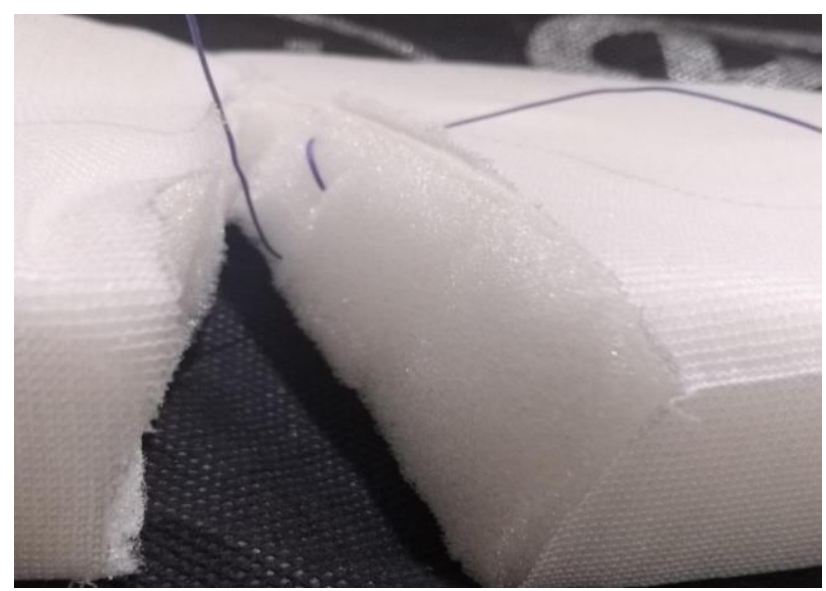

Figure 3: The second stitch is inserted on the deep muscle layer of the same side (Right side) of the episiotomy cutting then extracting needle.

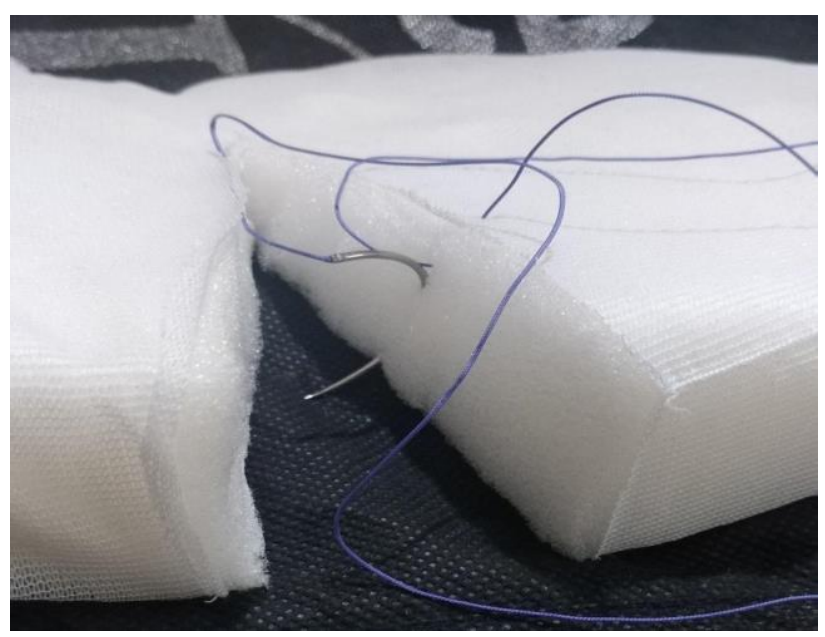

Figure 4: The second stitch is inserted on the deep muscle layer of the same side (Right side) of the episiotomy cutting then extracting needle. 


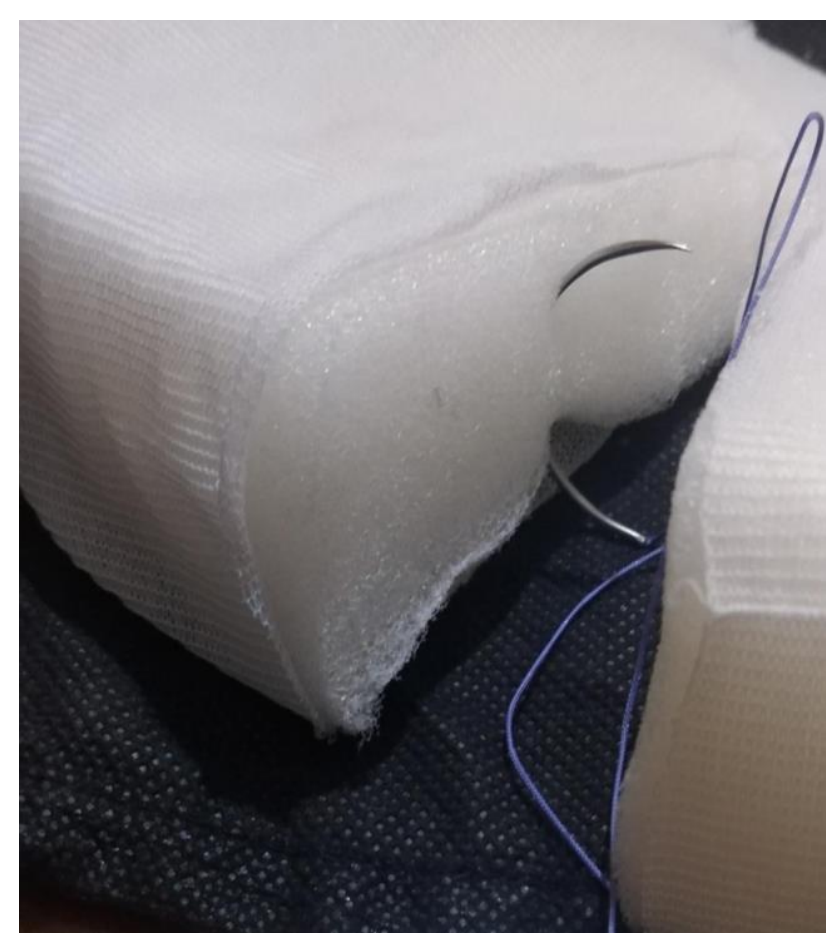

Figure 5: Then, we insert the needle again on the left side of the episiotomy incision in the deep muscle layer on left side of episiotomy incision directing the tip of needle upwards, parallel to the second stitch taken (as mentioned above).

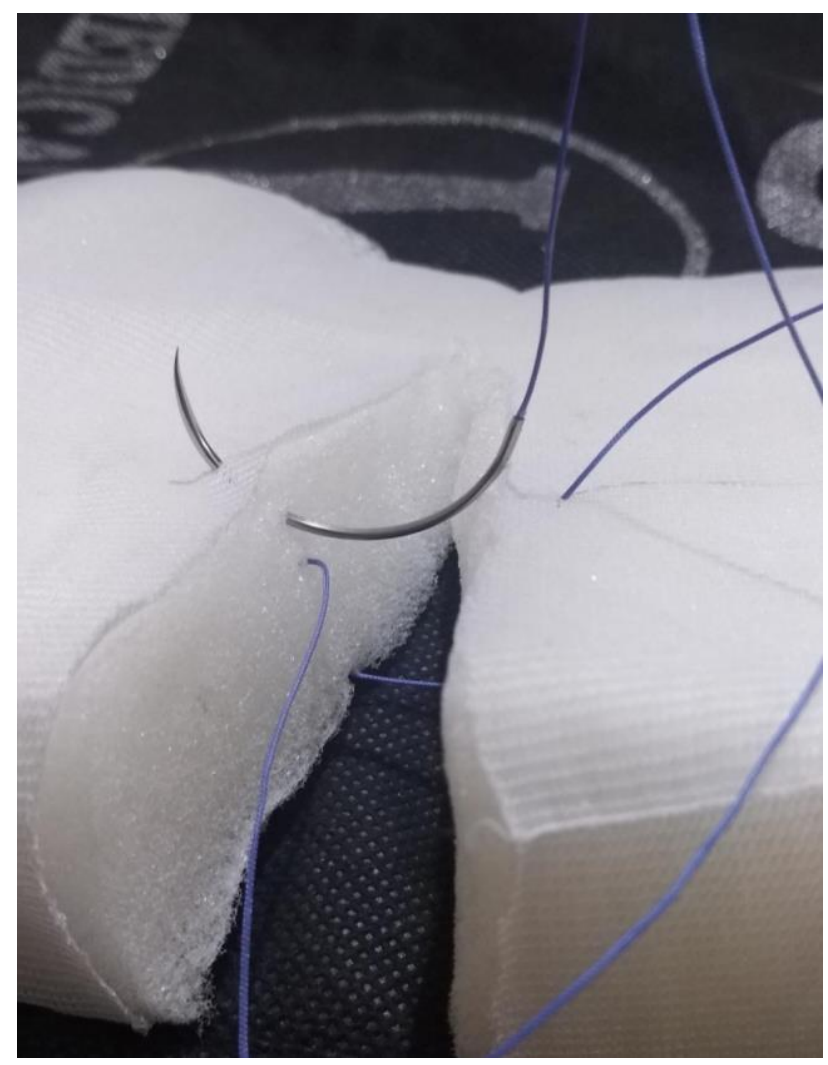

Figure 6: The fourth step is inserting the needle in the vaginal epithelium of the left side parallel to the first stitch.
Women are placed in the lithotomy position, and the local anaesthia is used for relieving patients from the pain.

The incised parts are cleaned and draped and good hemostasis is achieved.

Proper visualization of the apex of the episiotomy to prepare ourselves for suturing from the inside to the outwards.

The first simple suture is taken $(0.5 \mathrm{~cm})$ behind the apex of the episiotomy then we start to apply the new (Mostafa Maged Four-stitch technique) to get the vaginal epithelium and the deep muscle layer together at the same time at the same stitch with good hemostasis as well as tight approximation.

First, the needle is inserted at the vaginal epithelium of the right edge of episiotomy incision then we extract the needle.

The second stitch is inserted on the deep muscle layer of the same side (Right side) of the episiotomy cutting edge then extracting needle.

Then, we insert the needle again on the left side of the episiotomy incision in the deep muscle layer on left side of episiotomy incision directing the tip of needle upwards, parallel to the second stitch taken (as mentioned the above).

The fourth step is inserting the needle in the vaginal epithelium of the left side parallel to the first stitch.

We continue the suturing of the episiotomy incision in continuous manner in the same way till reaching the hymen ring boundaries.

Then, we introduce our finger between the two edges of episiotomy to make sure that the deep muscle layer is completely approximated and closed.

Then, we do the crowning suture, then, we suture the superficial muscle layer of the perineum in continuous manner as well as the skin in the sub-cuticular manner as well.

Rectal examination is applied to make sure that the sutures do not puncture the rectal epithelium.

The patients on discharge were already taken a prescription of broad-spectrum antibiotics.

The results were magnificent including: Prevention of the dead space formation, good and tight hemostasis of the episiotomy is achieved, strong approximation of the two edges of the episiotomy, cosmetically, it is so good as well for all patients (Table 1). 
Ali MM et al. Int J Reprod Contracept Obstet Gynecol. 2022 Jan;11(1):246-251

Table 1: Cases presentation after applying the technique.

\begin{tabular}{|c|c|c|c|c|c|c|c|}
\hline $\begin{array}{l}\text { Age } \\
\text { (years) }\end{array}$ & Parity & $\begin{array}{l}\text { Gestational } \\
\text { age (weeks) }\end{array}$ & $\begin{array}{l}\text { Current } \\
\text { mode of } \\
\text { delivery }\end{array}$ & $\begin{array}{l}\text { Outcome immediate post- } \\
\text { operatively }\end{array}$ & $\begin{array}{l}\text { Type of } \\
\text { episiotomy }\end{array}$ & $\begin{array}{l}\text { Hospital } \\
\text { stays } \\
\text { (Days) }\end{array}$ & Outcome of the (Mostafa Maged) new technique \\
\hline 26 & Primigravida & 37 & $\begin{array}{l}\text { Normal } \\
\text { vaginal } \\
\text { delivery }\end{array}$ & $\begin{array}{l}\text { Good (approximation of all } \\
\text { layers together is achieved and } \\
\text { good cosmetic appearance and } \\
\text { prevention of dead space } \\
\text { formation in the muscle } \\
\text { layers) }\end{array}$ & $\begin{array}{l}\text { Mediolateral } \\
\text { (deep and } \\
\text { extended) }\end{array}$ & e g g & $\begin{array}{l}\text { 1) Prevention of the dead space formation } \\
\text { 2) Good and tight hemostasis of the episiotomy is } \\
\text { achieved and less time unlike other techniques } \\
\text { which take a long time. } \\
\text { 3) strong approximation of } 2 \text { edges of episiotomy. } \\
\text { 4) cosmetically, it is so good. }\end{array}$ \\
\hline 28 & Primigravida & 38 & $\begin{array}{l}\text { Normal } \\
\text { vaginal } \\
\text { delivery }\end{array}$ & $\begin{array}{l}\text { Good (approximation of all } \\
\text { layers together is achieved and } \\
\text { good cosmetic appearance and } \\
\text { prevention of dead space } \\
\text { formation in the muscle } \\
\text { layers) }\end{array}$ & $\begin{array}{l}\text { Mediolateral } \\
\text { (deep and } \\
\text { extended) }\end{array}$ & 1 & $\begin{array}{l}\text { 1) Prevention of the dead space formation } \\
\text { 2) Good and tight hemostasis of the episiotomy is } \\
\text { achieved less time unlike other techniques which } \\
\text { take a long time. } \\
\text { 3) strong approximation of } 2 \text { edges of episiotomy. } \\
\text { 4) cosmetically, it is so good. }\end{array}$ \\
\hline 24 & Primigravida & 36 & $\begin{array}{l}\text { Normal } \\
\text { vaginal } \\
\text { delivery }\end{array}$ & $\begin{array}{l}\text { Good (approximation of all } \\
\text { layers together is achieved and } \\
\text { good cosmetic appearance and } \\
\text { prevention of dead space } \\
\text { formation in the muscle } \\
\text { layers) }\end{array}$ & Mediolateral & 1 & $\begin{array}{l}\text { 1) Prevention of the dead space formation } \\
\text { 2) Good and tight hemostasis of the episiotomy is } \\
\text { achieved less time unlike other techniques which } \\
\text { take a long time. } \\
\text { 3) strong approximation of } 2 \text { edges of episiotomy. } \\
\text { 4) cosmetically, it is so good. }\end{array}$ \\
\hline 22 & Primigravida & 37 & $\begin{array}{l}\text { Normal } \\
\text { vaginal } \\
\text { delivery }\end{array}$ & $\begin{array}{l}\text { Good (approximation of all } \\
\text { layers together is achieved and } \\
\text { good cosmetic appearance and } \\
\text { prevention of dead space } \\
\text { formation in the muscle } \\
\text { layers) }\end{array}$ & Mediolateral & 1 & $\begin{array}{l}\text { 1) Prevention of the dead space formation } \\
\text { 2) Good and tight hemostasis of the episiotomy is } \\
\text { achieved less time unlike other techniques which } \\
\text { take a long time. } \\
\text { 3) strong approximation of } 2 \text { edges of episiotomy. } \\
\text { 4) cosmetically, it is so good. }\end{array}$ \\
\hline 29 & Primigravida & 38 & $\begin{array}{l}\text { Normal } \\
\text { vaginal } \\
\text { delivery }\end{array}$ & $\begin{array}{l}\text { Good (approximation of all } \\
\text { layers together is achieved and } \\
\text { good cosmetic appearance and } \\
\text { prevention of dead space } \\
\text { formation in the muscle } \\
\text { layers) }\end{array}$ & Mediolateral & 1 & $\begin{array}{l}\text { 1) Prevention of the dead space formation } \\
\text { 2) Good and tight hemostasis of the episiotomy is } \\
\text { achieved less time unlike other techniques which } \\
\text { take a long time. } \\
\text { 3) strong approximation of } 2 \text { edges of episiotomy. } \\
\text { 4) cosmetically, it is so good. }\end{array}$ \\
\hline 30 & Primigravida & 37 & $\begin{array}{l}\text { Normal } \\
\text { vaginal } \\
\text { delivery }\end{array}$ & $\begin{array}{l}\text { Good (approximation of all } \\
\text { layers together is achieved and } \\
\text { good cosmetic appearance and } \\
\text { prevention of dead space } \\
\text { formation in the muscle } \\
\text { layers) }\end{array}$ & Mediolateral & 1 & $\begin{array}{l}\text { 1) Prevention of the dead space formation } \\
\text { 2) Good and tight hemostasis of the episiotomy is } \\
\text { achieved less time unlike other techniques which } \\
\text { take a long time. } \\
\text { 3) strong approximation of } 2 \text { edges of episiotomy. } \\
\text { 4) cosmetically, it is so good. }\end{array}$ \\
\hline
\end{tabular}

Continued. 
Ali MM et al. Int J Reprod Contracept Obstet Gynecol. 2022 Jan;11(1):246-251

\begin{tabular}{|c|c|c|c|c|c|c|c|}
\hline $\begin{array}{l}\text { Age } \\
\text { (Years) }\end{array}$ & Parity & $\begin{array}{l}\text { Gestational } \\
\text { age (Weeks) }\end{array}$ & $\begin{array}{l}\text { Current } \\
\text { mode of } \\
\text { delivery }\end{array}$ & $\begin{array}{l}\text { Outcome immediate post- } \\
\text { operatively }\end{array}$ & $\begin{array}{l}\text { Type of } \\
\text { episiotomy }\end{array}$ & $\begin{array}{l}\text { Hospital } \\
\text { stays } \\
\text { (Days) }\end{array}$ & Outcome of the (Mostafa Maged) new technique \\
\hline 31 & Primigravida & 36 & $\begin{array}{l}\text { Normal } \\
\text { vaginal } \\
\text { delivery }\end{array}$ & $\begin{array}{l}\text { Good (approximation of all } \\
\text { layers together is achieved and } \\
\text { good cosmetic appearance and } \\
\text { prevention of dead space } \\
\text { formation in muscle layers) }\end{array}$ & Mediolateral & 1 & $\begin{array}{l}\text { 1) Prevention of the dead space formation } \\
\text { 2) Good and tight hemostasis of the episiotomy is } \\
\text { achieved less time unlike other techniques which } \\
\text { take a long time. 3) strong approximation of } 2 \\
\text { edges of episiotomy. 4) cosmetically, it is so good. }\end{array}$ \\
\hline 33 & $\begin{array}{l}\text { Primigravida } \\
\text { with twins }\end{array}$ & 37 & $\begin{array}{l}\text { Normal } \\
\text { vaginal } \\
\text { delivery }\end{array}$ & $\begin{array}{l}\text { Good (approximation of all } \\
\text { layers together is achieved and } \\
\text { good cosmetic appearance and } \\
\text { prevention of dead space } \\
\text { formation in the muscle } \\
\text { layers) }\end{array}$ & Mediolateral & 1 & $\begin{array}{l}\text { 1) Prevention of the dead space formation } \\
\text { 2) Good and tight hemostasis of the episiotomy is } \\
\text { achieved less time unlike other techniques which } \\
\text { take a long time. } \\
\text { 3) strong approximation of } 2 \text { edges of episiotomy. } \\
\text { 4) cosmetically, it is so good. }\end{array}$ \\
\hline 28 & Primigravida & 38 & $\begin{array}{l}\text { Normal } \\
\text { vaginal } \\
\text { delivery }\end{array}$ & $\begin{array}{l}\text { Good (approximation of all } \\
\text { layers together is achieved and } \\
\text { good cosmetic appearance and } \\
\text { prevention of dead space } \\
\text { formation in the muscle } \\
\text { layers) }\end{array}$ & Mediolateral & 1 & $\begin{array}{l}\text { 1) Prevention of the dead space formation } \\
\text { 2) Good and tight hemostasis of the episiotomy is } \\
\text { achieved less time unlike other techniques which } \\
\text { take a long time. } \\
\text { 3) strong approximation of } 2 \text { edges of episiotomy. } \\
\text { 4) cosmetically, it is so good. }\end{array}$ \\
\hline 27 & Primigravida & 37 & $\begin{array}{l}\text { Normal } \\
\text { vaginal } \\
\text { delivery }\end{array}$ & $\begin{array}{l}\text { Good (approximation of all } \\
\text { layers together is achieved and } \\
\text { good cosmetic appearance and } \\
\text { prevention of dead space } \\
\text { formation in muscle layers) }\end{array}$ & $\begin{array}{l}\text { Mediolateral } \\
\text { (deep and } \\
\text { extended) }\end{array}$ & 1 & $\begin{array}{l}\text { 1) Prevention of the dead space formation } \\
\text { 2) Good and tight hemostasis of the episiotomy is } \\
\text { achieved less time unlike other techniques which } \\
\text { take a long time. } \\
\text { 3) strong approximation of } 2 \text { edges of episiotomy. } \\
\text { 4) cosmetically, it is so good. }\end{array}$ \\
\hline 25 & Primigravida & 35 & $\begin{array}{l}\text { Normal } \\
\text { vaginal } \\
\text { delivery }\end{array}$ & $\begin{array}{l}\text { Good (approximation of all } \\
\text { layers together is achieved and } \\
\text { good cosmetic appearance and } \\
\text { prevention of dead space } \\
\text { formation in muscle layers) }\end{array}$ & Mediolateral & 1 & $\begin{array}{l}\text { 1) Prevention of the dead space formation } \\
\text { 2) Good and tight hemostasis of the episiotomy is } \\
\text { achieved less time unlike other techniques which } \\
\text { take a long time. } 3 \text { ) strong approximation of } 2 \\
\text { edges of episiotomy. 4) cosmetically, it is so good. }\end{array}$ \\
\hline 20 & Primigravida & 38 & $\begin{array}{l}\text { Normal } \\
\text { vaginal } \\
\text { delivery }\end{array}$ & $\begin{array}{l}\text { Good (approximation of all } \\
\text { layers together is achieved and } \\
\text { good cosmetic appearance and } \\
\text { prevention of dead space } \\
\text { formation in muscle layers) }\end{array}$ & Mediolateral & 1 & $\begin{array}{l}\text { 1) Prevention of the dead space formation } \\
\text { 2) Good and tight hemostasis of the episiotomy is } \\
\text { achieved less time unlike other techniques which } \\
\text { take a long time. 3) strong approximation of } 2 \\
\text { edges of episiotomy. 4) cosmetically, it is so good. }\end{array}$ \\
\hline 22 & Primigravida & 38 & $\begin{array}{l}\text { Normal } \\
\text { vaginal } \\
\text { delivery }\end{array}$ & $\begin{array}{l}\text { Good (approximation of all } \\
\text { layers together is achieved and } \\
\text { good cosmetic appearance and } \\
\text { prevention of dead space } \\
\text { formation in muscle layers) }\end{array}$ & Mediolateral & 1 & $\begin{array}{l}\text { 1) Prevention of the dead space formation } \\
\text { 2) Good and tight hemostasis of the episiotomy is } \\
\text { achieved less time unlike other techniques which } \\
\text { take a long time. 3) strong approximation of } 2 \\
\text { edges of episiotomy. 4) cosmetically, it is so good. }\end{array}$ \\
\hline
\end{tabular}




\section{DISCUSSION}

Episiotomy has been carried out during labour to facilitate delivery, shorten the duration of the second stage and prevent spontaneous lacerations. However, recent studies of episiotomy have recommended that it be carried out only when necessary. ${ }^{9}$

Evidence does not support maternal benefits traditionally ascribed to routine episiotomy. In fact, outcomes with episiotomy can be considered worse since some proportion of women who would have had lesser injury instead had a surgical incision. ${ }^{10}$

Restrictive episiotomy policies appear to have a number of benefits compared to routine episiotomy policies. There is less posterior perineal trauma, less suturing and fewer complications, no difference for most pain measures and severe vaginal or perineal trauma, but there was an increased risk of anterior perineal trauma with restrictive episiotomy. ${ }^{10}$

\section{CONCLUSION}

The invention of this new technique (Mostafa Maged technique) has shown its effectiveness in those fifteen patients in preventing the dead space during suturing the episiotomy in primigravida cases. It is a new method, promising, easy, cheap and effective technique.

Funding: No funding sources Conflict of interest: None declared Ethical approval: Not required

\section{REFERENCES}

1. DeLee JB. The prophylactic forceps operation. Am J Obstet Gynecol. 1920;1:34.

2. Priddis H, Dahlen HG, Schmied V, Sneddon A, Kettle $\mathrm{C}$ et al. Risk of recurrence, subsequent mode of birth and morbidity for women who experienced severe perineal trauma in a first birth in New South Wales between 2000-2008: a population-based data linkage study. BMC Pregnancy Childbirth. 2013;08(13):89

3. Shmueli A, Gabbay Benziv R, Hiersch L, Ashwal E, Aviram R, Yogev Y et al. Episiotomy-risk factors and outcomes. J Matern Fetal Neonatal Med. 2017;30(3):251-6.

4. Khan NB, Anjum N, Hoodbhoy Z, Khoso R. Episiotomy and its complications: A cross sectional study in secondary care hospital. J Pak Med Assoc. 2020;70(11):2036-8.

5. Marty N, Verspyck E. Perineal tears and episiotomy: Surgical procedure-CNGOF perineal prevention and protection in obstetrics guidelines. Gynecol Obstet Fertil Senol. 2018;46(12):948-67.

6. Sultan AH, Thakar R, Ismail KM, Kalis V, Laine K, Räisänen $\mathrm{SH}$ et al. The role of mediolateral episiotomy during operative vaginal delivery. Eur $\mathbf{J}$ Obstet Gynecol Reprod Biol. 201;240:192-6.

7. Jiang H, Qian X, Carroli G, Garner P. Selective versus routine use of episiotomy for vaginal birth. Cochrane Database Syst Rev. 2017;2:CD000081.

8. Abdool Z, Thakar R, Sultan AH. Postpartum female sexual function. Eur J Obstet Gynecol Reprod Biol. 2009;145(2):133-7.

9. Karaçam Z, Eroğlu K. Effects of episiotomy on bonding and mothers' health. J Adv Nurs. 2003;43(4):384-94.

10. Hartmann K, Viswanathan M, Palmieri R, Gartlehner G, Thorp J Jr, Lohr KN. Outcomes of routine episiotomy: a systematic review. JAMA. 2005;293(17):2141-8.

11. Carroli G, Belizan J. Episiotomy for vaginal birth. Cochrane Database Syst Rev. 2000;(2):CD000081.

Cite this article as: Ali MM, Abd-Elfattah LE. The Mostafa Maged four-stitch technique to avoid leaving dead space during repairing the episiotomy. Int $\mathbf{J}$ Reprod Contracept Obstet Gynecol 2022;11:246-51. 